\title{
Study on the Established Measures for Urbanization and Industrialization on the Changwon General Mechanical Industrial Complex in South Korea
}

\author{
M. Ishii, S. Kanai, and H. Ohuchi
}

\begin{abstract}
The subject of this study is the "Changwon general mechanical industrial complex" in Changwon city, Republic of Korea, an improvement project that was completed with exceptional speed. This study aims to contribute useful data and information to those in developing countries who are focused on the balanced development of national territory in the course of industrialization and urbanization. As a result, the following four important points were obtained: first, enhancement of academic research and educational functions; second, strengthening the foundations of small and medium-sized enterprises; third, symbiosis and readjustment of systems of industrialization and urbanization; and fourth, the creation of the dynamism of the new regional formation in all respects.
\end{abstract}

Index Terms - South Korea Changwon, new city, developing countries, formation process, industrial location policy, urbanization, industrialization.

\section{INTRODUCTION}

By growth pole strategy, which is a fundamental strategy to achieve the aims of the first Comprehensive national development plan law, which came into operation in 1971, Changwon, which is located at the middle edge of Gyeongsangnam-do in the Republic of Korea (Fig. 1), was designated in April, 1974 as an "Industrial base developmental area" as a strategic base for developing machine industry based on Industrial base development enhancement ${ }^{1}$. Since then, it has become the country's first research city. In April 1974, construction work for the "Changwon General mechanical industrial complex" started with exceptional speed.

In this context, the South Korean Government at the time was showing an increasing tendency toward reducing dependence on the United States, including supplied weapons from the point of view of national security. The key was to achieve growth and development of the integrated machinery industry, which required an urgent improvement in regard to space and infrastructure.

At that time, the Changwon area was a farming region with a population of about ten thousand, which was known as Changwon-gun Changwon-myeon. In 2005, more than 30

Manuscript received December 20, 2013; revised February 12, 2014

Masao Ishii is with the Development Planning Institute Inc (e-mail: masao-ishii@dpi-inc.co.jp).

Setsuko Kanai is with Ohuchi architect and associates (e-mail: setsukoouchi@gmail.com).

Hirotomo Ohuchi is with Department of Architecture, College of Industrial Technology, Nihon University, Japan (e-mail: oouchi.hirotomo@nihon-u.ac.jp). years later, the population of Changwon was five hundred thousand, of which more than ninety thousand were industrial workers. It achieved the goals of the plan in record time and has grown to become one of the largest artificial cities ${ }^{2}$ in Korea.

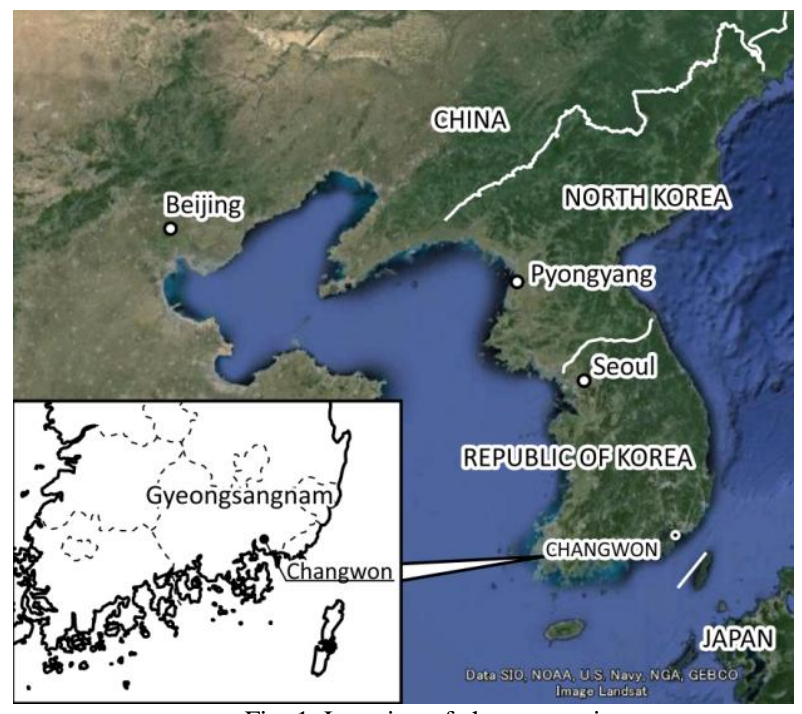

Fig. 1. Location of changwan city.

As described above, although the formation of the city was distinctive, there were few studies dedicated to the Changwon machinery industrial base. The research of Markusen et al., [1], Lee, Chul Woo et al., [2], Ishii, [3] and Tohiguchi[4] can be noted.

Today, more than 30 years have passed. Based on several field surveys and official references published by the Republic of Korea, the formation of this new city can be seen as an example for new cities. This study will examine the general background and the details of the project, the formation process, and the effects of the project. In this paper, following three points, background, current master plan, and effectiveness of the project proceeded are analyzed and discussed.

\section{BASIC VIEW OF "CHANGWON GENERAL \\ CONSTRUCTIONAL MASTER PLAN” FOR MACHINE INDUSTRIAL BASE}

The planning concept was based on the "Changwon General Constructional Master Plan For Machine Industrial Base," [5], [6] which was drawn up on the basis of the theoretical vision of an ideal world of "industrial park formation theory," in contrast to the Markusen perception of 
the Changwon machinery industrial estate.

\section{A. Project Planning Philosophy}

\section{1) Basic awareness for planning}

Since 1973, planning was mainly promoted by Economic Planning Agency and its related posts. Two Japanese think tank companies 3 and a South Korean engineering company have worked on the project in close cooperation. Concept planning was finalized in April, and research, and planning started in June, with a progress report scheduled for December. The three fundamental points of awareness in the planning are described below:

1) This plan is a serious effort to increase the production capacity of the machine industry, which is the weakest department in Korean industry, to the level of an advanced nation. However, the machine industry generally reaches full growth extremely belatedly among all industries. The Korean machine industry had forty-seven thousand workers at that time. The basic point of this plan is to raise the capacity of the machine industry efficiently and structurally in this area.

2) The machine industry develops by having organic relationships with related departments. It is important to aim at achieving various industrial accumulations. The machine industry has a deep relationship with urban functions of a high order in terms of the characteristics of location. Therefore, in this plan, it was thought that from both scale and structural aspects, "the new industrial city" that exceeded the so-called "industrial housing complex" above all has to be characterized as an "industrial capital" and the mainstay of the Korean machine industry.

3) Success in achieving the plan has great meaning, because it is a very grand plan, with some goals expected to be achieve in 1981, or 10 years later. Therefore, it is essential to have an unobstructed view of the consistent support policy of the administration authorities.

2) Planning conception of basic awareness

In realizing the planning ideology, three basic concept points were taken into consideration:

1) Every effort should be devoted to creating and developing three aspects in the setting up of this region as an "Industrial Capital."

a) That it should be a fully functioning new industrial city. In other words, the designers pursued a temporal and spatial development system of the industry and various technology-related features, including software and factory layout, based on the characteristics of the industry and district

b) To create such urban comfort as to lead to a sufficient new urban form in South Korea. This included a road network plan that corresponded to new proposals for community facilities by the residents, as well as clarification of the road function, such as the location of the Boulevard initiative, Central District Center, and the greater district center.

c) That landscape planning should be in harmony with nature and industry within the context of a positive environment in the basin.

2) The vision was not only to develop a major manufacturing area of industrial products, but also to bring about an"Industrial and Educational Complex" (Fig. 2) that would provide valuable human resources in the form of technicians and skilled workers, and thus assure Korea's future needs. Just as Tokyo Vocational School in Kuramae, Japan, has evolved into the Tokyo Institute of Technology, the Changwon district was intended to become the Korean Mecca of engineering education and research.

3) To design a buffer industrial zone. There are two general reasons for this strategy. Firstly, to ensure public guarantee for the acceptance conditions of related subcontracts. The maturity of the companies was an indicator of machinery industrial development in the region. The second reason for the buffer zone was to differentiate between a residential area and a restricted industrial district for commercial business, which ran along the main lateral line of the industrial zone.

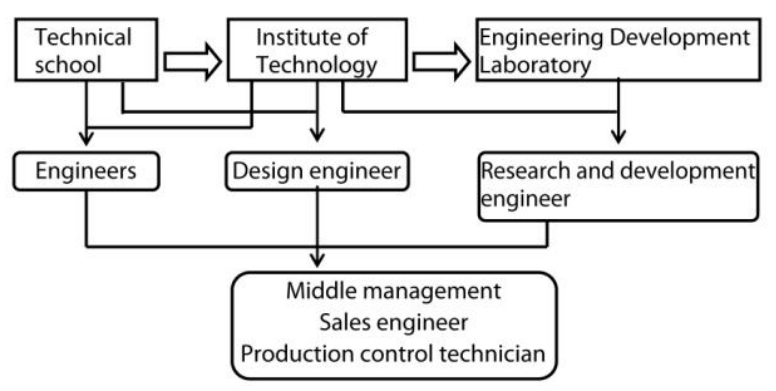

Fig. 2. Image of "industrial and educational complex".

\section{B. Outline of Basic Proposed Planning}

\section{1) Location}

The site is located $40 \mathrm{~km}$ to the west of central Busan. The site is about 5,000 ha, in a basin about 9,400ha in size that includes Changwon-gun, adjoins Masan-si, Sangnam-myeon, and is a major part of Ungnam-myeon and a part of Changwon-myeon.

There were six factors for selecting this region as a base for training in heavy machinery: 1) land-water conditions, 2) bearing capacity, 3) transportation costs and network, 4) terrain defense potential, 5) supply labor capacity, and 6) resident awareness of the manufacturing development (voices of opposition were few), which are all positive conditions.

\section{2) Main induced businesses and location}

The frame, which is shown in "Proposed longtime planning for cultivating machine industry" (September, 1973) by the Korean government, is set forth as a premise. Production costs were set at US $\$ 2,100,000,000$ (estimated exporting cost: US $\$ 600,000,000)$ and the factory site is 1,250 ha in size. The factory scale was set according to Japanese industrial statistics and adjusted for the location of the main factory and a model factory. Table I shows the main types of industry to be introduced and the amount of development across 20 categories. It is assumed that above flame will be accomplished with the product cost is JP\614,000,000,000 (US\$220,000,000,000, converted price; US\$1=JP $¥ 280$ ), exporting cost is JP¥220,000,000,000 (US\$800,000,000), the 
factory site area is 1180 ha in size, and 80000 workers.

TABLE I: LOCATION STATISTICS FOR CHANGWON GENERAL MACHINE INDUSTRIAL COMPLEX ${ }^{6}$

\begin{tabular}{|l|r|r|r|}
\hline & $\begin{array}{r}\text { Volume of } \\
\text { production } \\
\text { (mil./ Year) }\end{array}$ & $\begin{array}{c}\text { Factory } \\
\text { site area } \\
\text { (ha) }\end{array}$ & $\begin{array}{c}\text { Labor } \\
\text { force }\end{array}$ \\
\hline Formed and fabricated materials & 129,500 & 285 & 12,300 \\
\hline Parts & 76,000 & 140 & 9,000 \\
\hline Building-up & & & \\
\hline industrial machine & 82,500 & 165 & 13,000 \\
\hline consumer use machine & 10,000 & 20 & 2,000 \\
\hline transport machinery & 80,000 & 80 & 5,000 \\
\hline heavy electric machinery & 46,000 & 80 & 8,000 \\
\hline consumer use electronics & 110,000 & 100 & 10,000 \\
\hline minor business subletting & 80,000 & 310 & 21,000 \\
\hline Total & 614,000 & 1,180 & 80,300 \\
\hline Retren & & &
\end{tabular}

Reference: Changwon general constructional master plan for machine industrial base

TABLE II: LAND-USE PLANNING

\begin{tabular}{|c|c|c|}
\hline Land-use classification & Area(ha) & $\begin{array}{c}\text { Constituen } \\
\text { t ratio }(\%)\end{array}$ \\
\hline Heavy industry & 696 & 16.0 \\
\hline Light industry & 486 & 11.2 \\
\hline Machinery industrial 1 and & 255 & 5.9 \\
\hline Industrial logistics base & 267 & 6.1 \\
\hline Road and railway land & 324 & 7.4 \\
\hline High-rise housing site & 473 & 10.9 \\
\hline Low-rise housing site & 498 & 11.5 \\
\hline Center facility site & 109 & 2.5 \\
\hline Utility site & 40 & 0.9 \\
\hline Educational facility site & 45 & 1.0 \\
\hline Parks and green space land & 1093 & 25.1 \\
\hline Port facility site & 60 & 1.4 \\
\hline Total & 4346 & 100 \\
\hline
\end{tabular}

\section{3) Land use plan}

Land-use planning appeared in the Basic Plan (draft) under the concept. It contained the following characteristics:

1) Subject area for the land-use planning is approx. 4300ha.

2) A residential area is to be provided on the south incline away from the central flat area. The industrial zone is to be provided on the flat area to the north of the incline. In addition, the One-Center System was allocated land in the central part, which consists of commercial, business and public service facilities in the form of a district center/ central facility site. The industrial zone side consists of education and training facilities, as well as research-and-development (R\&D) operations, that are directly linked to production. The Central District, which is combined with urban facilities, is envisaged as an educational facility site.

3) A Buffer Industrial Zone is planned for the approx. 214 ha intermediate zone of the boulevards and the river. This buffer zone is to be developed as a symbol zone of this district with sufficient green space and a good environment industrial zone for small and medium-sized companies. In regard to the Flatted Factory (factory buildings), it is assumed to develop it as a symbol zone. Further, the type of Flatted Factory that increases the productivity of the land area more than conventional methods will be considered, and it is also possible to ensure a sufficient open space in the center area of - the buffered industrial zone.

4) The residential district was developed in the form of low-rise independent residence and high-rise collective housing (housing land).Changwon, Korea's new industrial city plan, is to be organized according to the proposal of the Republic of Korea Government on the basis of the Basic Plan. The land-use plan (shown in Table II is represented in the final draft.

\section{SKETCH OF NEW INDUSTRIAL CITY FORMATION PROCESS}

\section{A. Development of the Rapid Industrialization}

The speed of industrialization of the Changwon synthetic machine engineering base is shown in Fig. 3. In 1974, when industrialization started, there were already 14 factories. By 1978, there were 122 factories with 30,000 employees. The number of employees of the original plan has been exceeded.

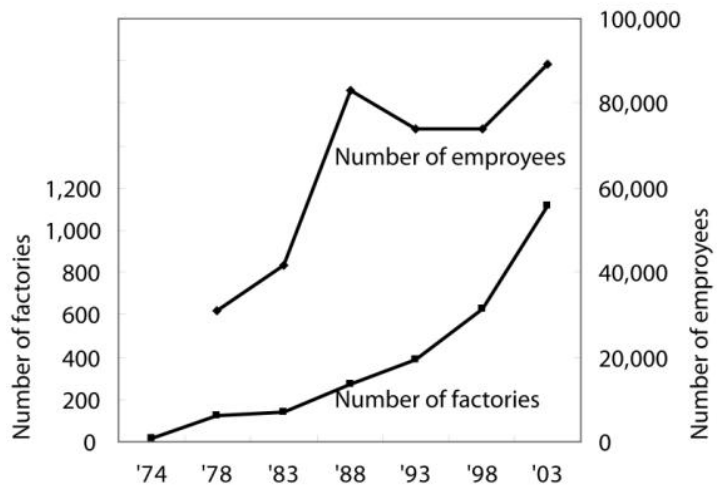

Fig. 3. Changes in population and number of employees.

By 1988, there were 271 factories employing 83, 215 people. At present, 2003, all sites are developed, and there are more than 1,000 factories employing 90,000 workers. In the whole of Changwan city, there are about 1, 800 factories and about 94,000 employees, and the Changwan synthetic dynamic engineering base is the foundation. The construction work progressed smoothly owing to the strong support of the government in implementing the policy on the location of firms representative of South Korean entrepreneurship, such as Doosan Heavy Industries \& Construction; Samsung Electronics Co., Ltd.; LG Electronics Inc.; GM Daewoo Auto \& Technology Company; and Tong-II Heavy Industries Co., Ltd; the policy also included stipulations on the location of foreign enterprises such as Volvo and Denso Corporation that have set up operations in Changwon-si, which functions as their production foothold in the Pacific area. As shown in the industry composition table (Table III), in 2005, the machine industry was the main constituent, and the accumulation of different industries is proceeding according to the original plan. The machine industry base remains the foundation in both name and reality.

However, according to interviews, as time passes, the mutual network of the companies and management information of the companies in the industrial park gradually develops into one of cooperation.

For example, companies subcontracted to prop up growth and development of the machinery industry also expanded 
significantly after a set period of 30 years. The ratio of outsourcing of the automotive industry is about $40 \%$ (value ratio), and there are about 100 outsourcing companies. Further increase is expected in future, and it is a challenge to promote the strengthening of the foundation of small and medium-sized enterprises.

In addition, industrial worker numbers are growing steadily, as mentioned above, but as for researchers and engineers, there are numerous unaccompanied single persons who have found it difficult to leave the capital of Seoul with their families. The educational environment for children and employment opportunities for married women, as well as the building of an attractive urban environment, have become issues for these researchers and engineers.

TABLE III: NUMBERS OF MAIN INDUSTRY-CLASSIFIED FACTORIES AND

\begin{tabular}{|l|r|r|r|}
\hline WORKERS \\
\hline Category & $\begin{array}{c}\text { production } \\
\text { (mil. won) }\end{array}$ & factory & worker \\
\hline Chemical goods & 5,88100 & 66 & 2,309 \\
\hline Nonmetallic mineral manufacture & 1,44200 & 18 & 873 \\
\hline Primary metal manufacture & 38,19600 & 76 & 6,034 \\
\hline Metallic manufacture & 3,99500 & 389 & 14,406 \\
\hline General machinery & 160,86100 & 735 & 34,129 \\
\hline Electricity and electronics device & 34,58900 & 226 & 11,233 \\
\hline Precision equipment & 3,81500 & 67 & 2,508 \\
\hline Transport machine & 62,04300 & 242 & 18,948 \\
\hline Others & 41,51900 & 131 & 2,935 \\
\hline Total & 352,34100 & 1,950 & 93,375 \\
\hline Reference: Statistical annual report of Changwon $(2005)$ \\
\hline
\end{tabular}

\section{B. Location of Industrial Support Facility}

In regard to industrial support facilities for urban functions, there are three universities (more than 70 departments with the number of students exceeding 5,000), including the Korean Institute of Machinery (Integrated Korean shipbuilding Institute and Korea machine metal testing laboratory), and the Korea Electro Technology Research Institute. Changwon Convention Center, which serves as an exhibition space, the Convention Center, the Technology Support Center, the Small Business Support Center, and the southeast regional industrial park management corporation, which manages the governmental industrial park in the southeast region, are all consolidated.

The commercialization of the facility development has been going on since the technopolis of the $80 \mathrm{~s}$.

In the formation of Changwon in the 70s, those developments of the functions can be seen in a planning mindset that cannot be captured by only one side, such as "development and military dictatorship."

In this way, the business service functions of the new city of Changwon are being gradually enhanced. However, it can be pointed out that universities and research institutions conceived as the core function do not exhibit sufficient functionality. This has also been pointed out by Lee and Marksen et al, and Chul Woo et al.

In this context, three factors should be highlighted. First, the level of military industry is relatively low in this location. Second, the cost of $R \& D$ investment to increase $R \& D$ capacity is low. Third, there exists a view that Korea is reluctant to invest in studies rooted in university.

Changes are under way, however, that will affect the situation, from military demand to civil demand and their relationship with the universities and research institutes. Maintenance and enhancement of industry support functions has become an important issue. It is generally believed that this kind of improvement and enhancement is linked to the promotion of regional innovation.

\section{Formation of City Area}

Like the industrial area, development of the new city area is proceeding, albeit slowly. These businesses materialized after "Changwon new city design" was finalized in 1979. Municipalization in 1980 added considerable momentum to the development of the city.

In particular, the relocation of the Provincial Office from Busan to Changwon in 1983 directly affected not only the 53 agencies in the prefectural units, representing some 2,100 civil servants, but also affected tertiary institutions of all sorts. A major impetus was brought to the main regional urban area of Gyeongnam Province from that of the new industrial city. Fig. 4 shows the rapid increase in total population during this period. Just before the development in 1973, there were approximately 10,000 people in farming villages, which were dramatically transformed through large-scale industrialization. Seven years later, in April of 1980, two regions adjacent to Changwon City were merged. The new city of Changwon was established on 12,740 ha, with a population of 120,000 . Eight years later, the male population passed the original target, which was for a population of 260,000 .

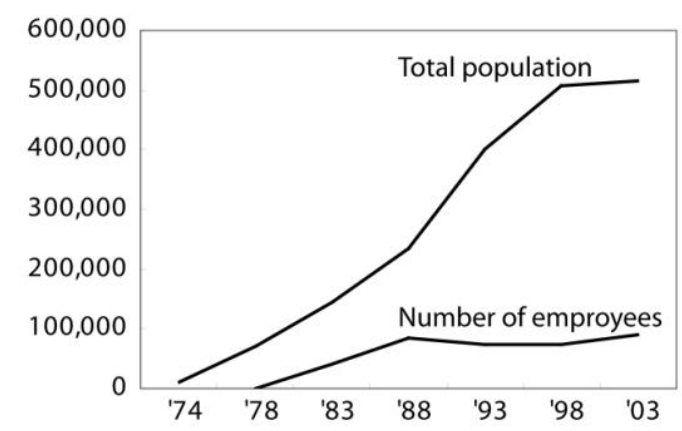

Fig. 4. Changes in population and number of employees.

The rising trend for the total population after that has never declined. In 2005, the population exceeded 500,000, and the city planning zone will be expanded.

The increase in population until the middle of 1980's was in the form of a synergistic effect of direct and indirect factors and the city-fixation factor of the suburban commuter population due to industrialization. But after the prefectural agency moved to the city, the population increase is due to people being drawn to the city from adjacent areas by the direct and indirect factors related to the functions of the administrative core.

Problems with traffic and welfare facilities caused by urban centralization due to rapid population growth in excess of population forecasts soon arose, along with shortages of cultural facilities, including schools, not to mention a dramatic change in lifestyle for local citizens. Hence, challenges soon arose of how to deal with such problems. 


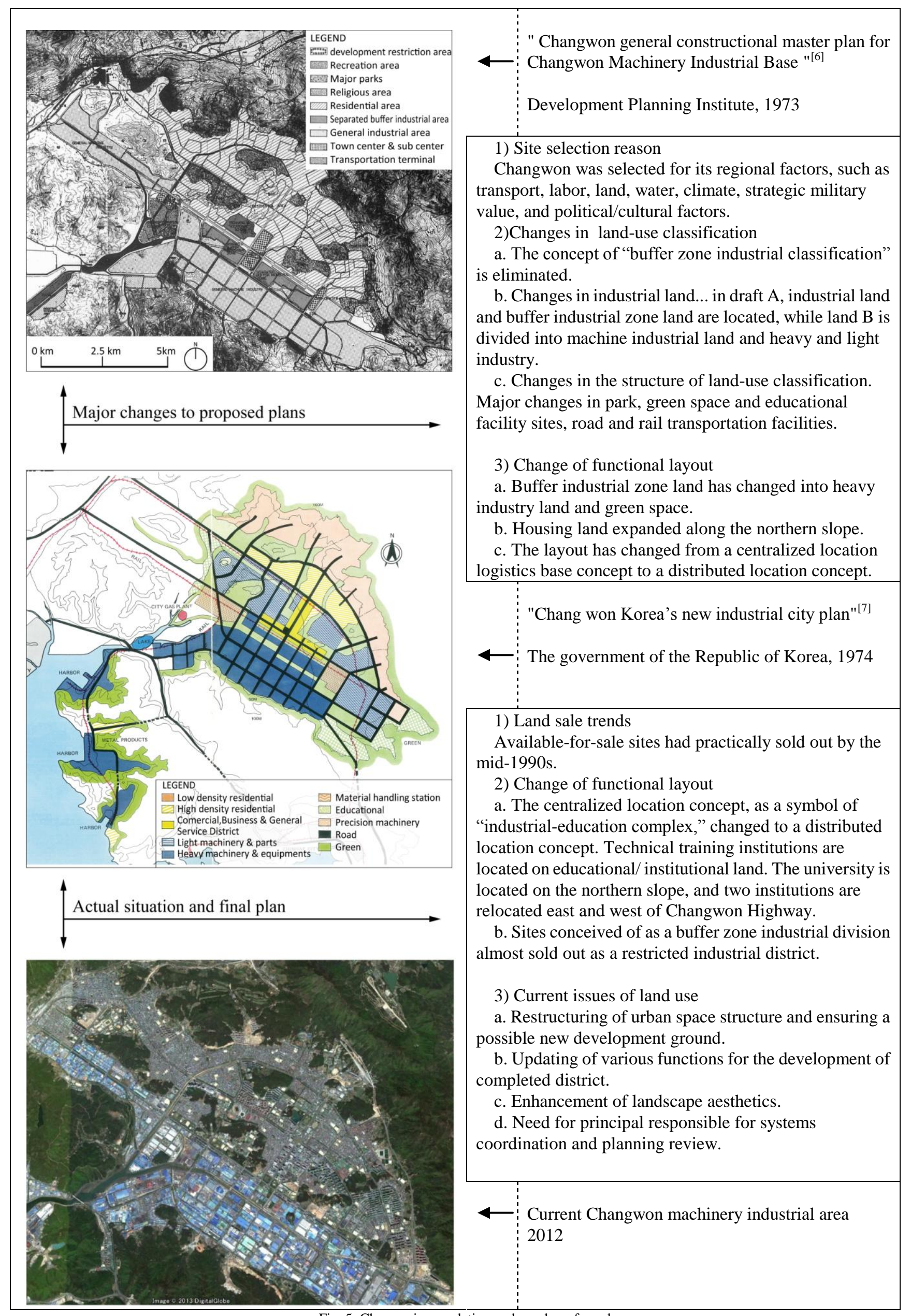

Fig. 5. Changes in population and number of employees. 


\section{Changes in Various Functions and Location Land-Use Planning}

As it has been studied so far, "Changwon machinery industrial park" indicates the progress originally planned. Nevertheless, in the course of 30 years there have been a number of inconsistencies between the location of the various functions and the original plan. These transitions are shown in Fig. 5; characteristic events are illustrated.

In the mid-1990s, available sites were nearly sold out. The background and factors related to changes in land use during this period are difficult to summarize. However, the following four points can be highlighted as present-day issues of land use. First, restructuring of urban space structure and ensuring of the new development ground. Second, updating of various functions of the completed development region. Third, the promotion of landscape aesthetics. Fourth, the whole concept of an operating body responsible for the coordination of the systems and review of land-use planning.

\section{CONSIDERATION OF AN IMPLIED MATTER}

As stated above, since apartment complexes had been built in villages located in secluded areas, industrialization was promoted and city planning was initiated 30 years in advance. Against this background, there were a number of developments: the smooth progress of construction activity,

enactment of special laws, the facilitation of city development, the appearance and introduction of a prefectural agency, consistent support by the Korean governmental authorities, and the ingenuity and effort of the related authorities. In addition, after the latter half of the 1970s, the South Korean economy entered a phase of rapid growth; this was a time when South Korea took up a bold challenge to make the transition from a developing country to an advanced economy. This was also when the large-scale national project of city development was accomplished.

According to the 30-year analysis, the framework for the various sections that might appeal to developing countries aiming for industrialization and urbanization is illustrated as follows:

\section{1) Academic, research, and educational functions}

Innovations of established techniques serve as the driving force for industrial development. This necessitates a close mutual relationship between the technologies developed by institutes, business organizations, and university-affiliated research institutions, as well as the promotion of research ability and technological skill.

Its importance was shown in Silicon Valley in the United States and in the Techno Polis policy of Japan. As described above, it was conceived ten years ahead of Techno Polis construction in Japan. However, as pointed out earlier, with regard to the current situation of Korea and Changwon, there is a feeling that the momentum of exchange and cooperation of mutual company and research institutions has not yet gained general appeal. Further, the growth of institutions to mediate these interactions and coordinate them seems to be somewhat inferior to that in developed countries.
In the current industrial location, with a weight equal to or greater than approximately the development of land, and with various water and transportation facilities, it is an important location condition to form the system that promotes the exchange and fusion of technology development combined with advanced $\mathrm{R} \& \mathrm{D}$, a vital element for future planning themes.

2) Strengthen the base of small business

As described above, with the lapse of 30 years, it can be seen that the formation of the subcontractors' small and medium enterprises has made progress, and further increase is predicted. In general, however, it seems that the level of industrial productivity of the region is determined by large companies regardless of how much small and medium-sized businesses take root in the region, and this is more important than whether or not medium-sized companies and $\mathrm{R} \& \mathrm{D}$-based ventures are heading in the right direction. Along with the physical proximity of the subcontracting companies, it is important to build a cooperation system with the core facilities to support the development and exchange of technical and management capabilities of micro, small, and medium-sized enterprises and to develop the measures to strengthen planned corporate foundations.

\section{3) Symbiosis of urbanization and industrialization}

As previously discussed, the 214 ha of buffer industrial zone in the original plan is now almost sold out (as a restricted industrial district). There are institutional constraints to advance the symbiosis of industrial area and green space. Furthermore, the companies that located early in the city formation assumed that the area, which is close to the high-rise housing along the boulevards, would be extremely attractive as a site for an industrial basis.

The review of the resilient plan and the way of the coordination of the system are important factors for achieving a symbiotic expansion by linking industrialization and urbanization for the effective recognition of the industrial location policy.

4) Creation of the dynamism of the new regional formation

While the formation of the new city of Changwon is contributing to the decentralization of industry in South Korea and the correction of income disparities between regions, challenges remain. In order for Changwon to achieve growth and continuous development, the city needs to foster regional dynamism through innovation, collaboration, and interdisciplinary policy or cross-sector policy systems that build on past policy. As the saying goes, "urban development is a half-century business," and the 35-odd years since the announcement of the "industrial base development area," the axis of production activities has changed from the military to the private sector while the building of the comprehensive and systematic scenario of Changwon now holds an important significance, which indicates that it is now in the second phase.

5) Corresponds to the generation of new challenges

The issues raised above show that Changwon has faced the challenge of reorganizing the structure of urban space with the aim of "re-creating the development power" and renovating dilapidated infrastructure while beautifying the surroundings, 
especially in those areas where developmental activity has taken place. Another challenge was to make Changwon the environmental capital of the Republic of Korea by 2008 when the Ramsar General Meeting was scheduled to be held. In this way, qualitative growth has been pursued in a way appropriate to the mature state of the city.

Over 30 years have passed since Changwon was developed as the first artificial city by means of city planning, and several challenges were encountered and overcome in this effort. Hence, the above approaches can prove to be valuable for advancing countries that are moving toward industrialization and urbanization in the future.

\section{ACKNOWLEDGMENT}

The authors thank deeply Mr. Jiro Watanabe, full member of Japan Society of Urban and Regional Planners, who supported us for providing data, actual condition of Changwon, and process of development "Changwon general constructional master plan for machine industrial base."

\section{NOTES}

This promotion law was established to mainly promote heavy industry taking declining of it opportunity. It aims to contribute development of industrial base and population, designation of special area for balanced location of industry, water source, and national economics.

Industorial base is projected in Pohang, Gumi, and Yeocheon besides Changwon.

Markusen and Park state that the construction of the "Changwon machinery industrial park" was strongly associated with military industry and military and political activities at the time. They generate five hypotheses that the priority of the location in the development and construction was different from that of the private sector. In order to verify this, confidential interviews with defense analysts were held and an analysis of public documents related to the management of Changwon was carried out. As a result, it was deemed that not all of the hypotheses rang true, with the weakness being that because priority was given to military effectiveness, there was a limit to function as the main core of innovation in Korea.

Lee, Chul Woo et al., 4 carried out a questionnaire survey of companies and interviewed CEOs and administrative executives about regional systems of innovation. They found that a network of suppliers and a local labor market had been established in the "Changwon machinery industrial park" but that local governments, research centers, and universities did not play much of a role in the construction of regional innovation.

Master plan was conducted by Development Planning Institute Inc. (Retired president and research special adviser, Mr. J Sasao) and Takken city planning consultants (corporate officer Mr. T Oba), receiving a commission from South Korean government.

In the table, "Formed and fabricated materials" indicates special steel , pig-iron casting, mold tool, and electrical cable, and "Parts" indicates bearing, spring, auto parts etc.

The technopolis attempted to simultaneously achieve the goal of a high value-added or creative technology-oriented nation, as well as pursuing knowledge intensification of the industry structure and development of the region toward the 21 st century by attaining the type of urban development that harmonizes with "industrials" (high-tech industry group), "studies" (academic research institutes and research institutes), and "housing," which translates as a pleasant and comfortable living environment that incorporates the vitality of the advanced technology industry with abundant nature, culture and tradition of community.

\section{REFERENCES}

[1] A. Markusen and S. O. Park "The state as industrial locator and district builder: the case of Changwon, South Korea," Economic Geography, vol. 19, pp. 157-181, April 1993.

[2] C. W. Lee, H. S. Kang, and K. Park, "Regional innovation systems in Korea: with reference to Taejon and Changwon," presented at the 2nd ICGG Conference, Taegu, South Korea, August 9-13, 2000

[3] M. Ishii, "Research related to the relevant challenges and the formation process of the new cities: Changwon (Republic of South Korea)," AIJ Journal of technology and design, no. 26. 2007

[4] T. Jeon and M. Tohiguchi, "A Study on the Changing of National Land space Structure and Regional Development Policy of Korea," City planning 232, vol. 50, 2001

[5] Development Planning Institute Inc., Framework of the placing and the outline of the law of various quantities of the location of the Changwon Machinery Industrial Base (memorandum of understanding), Japan, 1973

[6] Development Planning Institute Inc., Changwon general constructional master plan for Changwon Machinery Industrial Base, Japan, 1973

[7] The government of the Republic of Korea., Changwon Korea's new industrial city plan, Korea, 1973

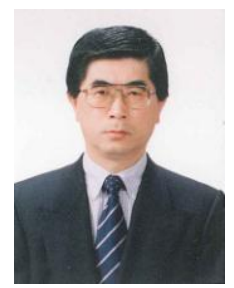

Masao Ishii was born in Tokyo, Japan in 1951. He received M. Eng degree in the department of industrial engineering speciality from Nihon University graduate student of engineering in 1977. He is currently President of Development Planning Institute Inc. His study field are listed below:

Research on typological chracterics based on a survey of the actual state of public and improvement housing.

Fundamental Study on location formation mechanism of new regional industries.

Research related to the relevent challenges and the formation process of new cities: Changwon, Republic of South Korea

Research on the dynamism formation by participation and cooperation of the citizen level towards independence-ization of an independent type district smallness city zone over a very wide area.

Study of regional character of small towns in countryside and forming the social basement of intelligence.

Substanial research on the dynamism of a local small city promotion a fact analysis of Imari city affairs for thirty five years.

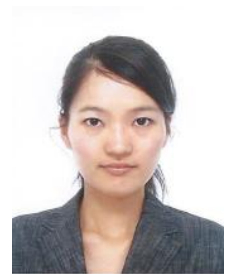

Setsuko Kanai was born in Chiba, Japan in 1983. She received bachelor of arts degree in education from Soka University, Tokyo, Japan in 2007, and received bachelor of fine arts degree from Kyoto University of Art and Design, Kyoto, Japan in 2012.

She is now a researcher at Ohuchi architect and associates and a master's degree student at European University of Madrid.

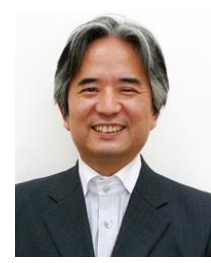

Hirotomo Ohuchi was born in Tokyo, Japan 1954. He received Doctor of Engineering from Nihon University. He is currently professor architect at Department of Architecture in Nihon University and the principal of Ohuchi architect and associates.

He is a Japan registered architect and a member of Japan Institute of Architects and member of Architectural Institute of Japan. He has won many awards, notable among them being the Academy of France Architects Award in the International Architectural Design Competition For students from UIA (International Union of Architects) and The Poland Award in the International Urban Design Competition for Young Architects in 1990 from UIA (International Union of Architects). 